Open Access

\title{
Summing the strokes: energy economy in northern elephant seals during large-scale foraging migrations
}

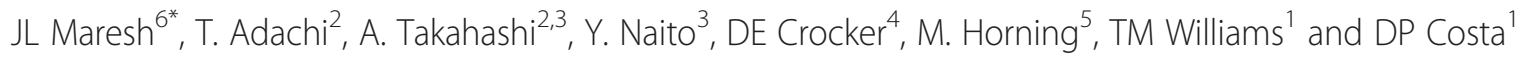

\begin{abstract}
Background: The energy requirements of free-ranging marine mammals are challenging to measure due to cryptic and far-ranging feeding habits, but are important to quantify given the potential impacts of high-level predators on ecosystems. Given their large body size and carnivorous lifestyle, we would predict that northern elephant seals (Mirounga angustirostris) have elevated field metabolic rates (FMRs) that require high prey intake rates, especially during pregnancy. Disturbance associated with climate change or human activity is predicted to further elevate energy requirements due to an increase in locomotor costs required to accommodate a reduction in prey or time available to forage. In this study, we determined the FMRs, total energy requirements, and energy budgets of adult, female northern elephant seals. We also examined the impact of increased locomotor costs on foraging success in this species.

Results: Body size, time spent at sea and reproductive status strongly influenced FMR. During the short foraging migration, FMR averaged $90.1(\mathrm{SE}=1.7) \mathrm{kJ} \mathrm{kg}^{-1} \mathrm{~d}^{-1}$ - only $36 \%$ greater than predicted basal metabolic rate. During the long migration, when seals were pregnant, FMRs averaged $69.4( \pm 3.0) \mathrm{kJ} \mathrm{kg}^{-1} \mathrm{~d}^{-1}$ - values approaching those predicted to be necessary to support basal metabolism in mammals of this size. Low FMRs in pregnant seals were driven by hypometabolism coupled with a positive feedback loop between improving body condition and reduced flipper stroking frequency. In contrast, three additional seals carrying large, non-streamlined instrumentation saw a four-fold increase in energy partitioned toward locomotion, resulting in elevated FMRs and only half the mass gain of normally-swimming study animals.

Conclusions: These results highlight the importance of keeping locomotion costs low for successful foraging in this species. In preparation for lactation and two fasting periods with high demands on energy reserves, migrating elephant seals utilize an economical foraging strategy whereby energy savings from reduced locomotion costs are shuttled towards somatic growth and fetal gestation. Remarkably, the energy requirements of this species, particularly during pregnancy, are 70-80 \% lower than expected for mammalian carnivores, approaching or even falling below values predicted to be necessary to support basal metabolism in mammals of this size.
\end{abstract}

Keywords: Accelerometer, Aerobic dive limit, Body size, Disturbance, Field metabolic rate, Foraging, Hypometabolism, Locomotion, Pregnancy

\footnotetext{
* Correspondence: jmaresh@ucsc.edu

${ }^{6}$ University of California Center for Ocean Health/Long Marine Lab, 100

Shaffer Rd., Santa Cruz, CA 95060, USA

Full list of author information is available at the end of the article
}

\section{Biomed Central}

(c) 2015 Maresh et al. Open Access This article is distributed under the terms of the Creative Commons Attribution 4.0 International License (http://creativecommons.org/licenses/by/4.0/), which permits unrestricted use, distribution, and reproduction in any medium, provided you give appropriate credit to the original author(s) and the source, provide a link to the Creative Commons license, and indicate if changes were made. The Creative Commons Public Domain Dedication waiver (http://creativecommons.org/publicdomain/zero/1.0/) applies to the data made available in this article, unless otherwise stated. 


\section{Background}

Upper-trophic-level predators are important components of food webs, having disproportionate, landscapelevel effects on the structure and function of ecosystems $[1,2]$. Recent reductions in many species of large marine carnivores, including marine mammals, sharks and piscivorous fishes, have prompted calls for effective ecosystem-based management targeted at recovering depleted populations, while proactively protecting intact populations from decline [3-5]. As a result, many studies have focused on describing the distributions and foraging success of these groups in relation to habitat features [e.g., 6] and prey distributions [e.g., 7] with little information available on the basic resource needs of these species. Assessing the prey requirements of highlevel predators is also central to determinations of how resilient they might be to ongoing anthropogenic disturbance and rapid environmental change [8]. In contrast to many terrestrial systems, information on energy requirements is difficult to come by for marine animals because they forage at sea, making their food habits and foraging behaviors challenging to directly measure.

In general, marine mammals have large energy requirements that are thought to be driven by the relatively large metabolic demands prescribed by carnivory [9] and the maintenance of a high core body temperature in water [10]. Foraging effort will reflect these requirements, and will contribute to energetic demands via the costs associated with locating, chasing and capturing prey [11]. To remain in positive energy balance, the energy acquired from foraging must exceed the energetic cost of foraging [12]. More successful foragers will accumulate surplus energy to allocate towards somatic growth and reproduction, and thus, a high foraging efficiency via the minimization of energy expenditure relative to energy gain is expected to be adaptive for all animals, and especially for predators with large energy requirements. Marine animals can minimize locomotion costs by adoption of stereotyped swimming behaviors. For example, "widely foraging" [13] individuals regularly engage in specific swimming modes [14], swim at particular speeds and depths [15], and utilize energysaving swimming strategies like drift diving [16, 17], burstand-glide swimming [18], porpoising [19] and wave-riding [20]. The disruption of these routine behaviors should increase the amount of time and energy spent foraging, resulting in increased locomotory costs and less energy devoted to production, thereby reducing foraging success.

The ecology of the northern elephant seal, Mirounga angustirostris, (Fig. 1) facilitates acquisition of foraging behavior data using archival tagging instrumentation, making it an ideal study species to address questions on the effects of both natural and anthropogenic disturbance on the foraging success of marine carnivores. Every year, adult females return to land for one month in between each of two foraging migrations, once to birth and nurse a pup, and once to molt their pelage [21]. Females are inseminated just prior to weaning, and then return to sea to forage for $2-2.5$ months before hauling out for the molt. Implantation likely occurs during or after the molt, when seals return to sea for 7-8 months to forage and gestate the fetus. The demands for foraging success are considerable during this time, as pregnant seals must ingest sufficient energy to replace what was lost during the molt as well as store sufficient energy reserves to support the fasting mother and her suckling pup during the costly month-long lactation period [22].

Our objectives in this study were to determine the total energy requirements, and the relative partitioning of energy among competing demands, for adult female northern elephant seals under normal foraging conditions. We compare these data to those from 3 seals encountering increased foraging costs due to increased drag, to determine how the disruption of stereotyped locomotory behaviors affects energy balance. To achieve this, we constructed complete energy budgets by coupling measurements of foraging success (energy gain) during each foraging migration with empirical measurements of locomotion costs in free-swimming seals [23]. For one of the largest predators in the northern Pacific Ocean, we describe (1) increased, extreme energy economy as a function of pregnancy and/ or time spent at sea; (2) strong, predictive relationships between body size, flipper stroking mechanics, and at-sea energy expenditure; and (3) reduced foraging success when stereotyped, energy-saving swimming behaviors are disrupted.

\section{Results}

\section{Energy expenditure}

Energy expenditure for each of the 22 seals carrying accelerometers is listed in Table 1 . For each of the variables discussed below - field metabolic rates (FMRs), locomotion costs, and flipper stroking frequency - the response was influenced by the interaction between body size and foraging migration (short or long trip) (MLR results, $p<0.05$ for each). The significant interaction term indicates that the relationship between mass and each response variable depends on the migration, so we ran MLRs on each of the migrations separately. As described below, our data indicate that, in general, locomotion behavior and the resulting field energetics of seals were most influenced by time spent at sea during the short trip, and the animal's mass during the long trip. For both migrations, variance in calculations of FMR was most sensitive to estimates of CPS (Additional file 1: Table S.1); sensitivity of calculations of locomotion costs was spread among estimates of how ingested energy was partitioned among the input parameters E(Feces + Urine + Digestion + Maintenance) (Additional file 1: Table S.2) 


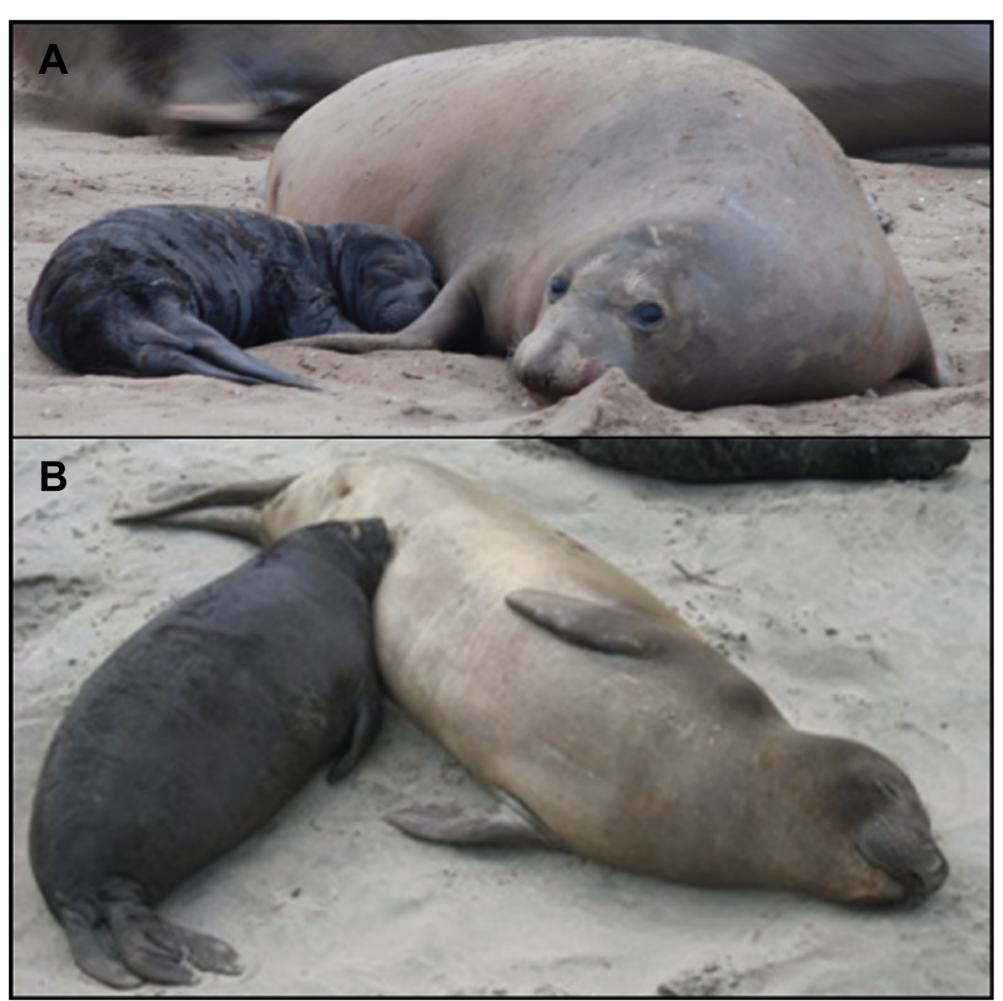

Fig. 1 Northern elephant seal (Mirounga angustirostris) mother with a young pup (1-2 d) and b pup just before weaning (25-28 d). Photo credits: D. Costa, M. Fowler

\section{Short trip}

At-sea FMRs during the shorter migration averaged $91.0 \pm 1.7 \mathrm{~kJ} \mathrm{~kg}^{-1} \mathrm{day}^{-1}$, ranging from 1.2-1.5 times Kleiber predictions of BMR. There was a weak although not statistically significant predictive relationship between mass-specific FMR during the short trip, and mass and time spent at sea according to the equation:

$$
\begin{aligned}
\text { FMR }_{\mathrm{ST}} & =41.0 \mathrm{M}^{-0.21} t^{0.51}\left(\mathrm{r}^{2}=0.33, \mathrm{~F}_{2,10}\right. \\
& =2.455, p=0.14)
\end{aligned}
$$

where $\mathrm{FMR}_{\mathrm{ST}}$ is field metabolic rate during the short trip in $\mathrm{kJ} \mathrm{kg}^{-1} \mathrm{~d}^{-1}, \mathrm{M}$ is mass in $\mathrm{kg}$, and $t$ is time spent at sea in days. Despite its low predictive $\left(r^{2}\right)$ value, eq. [2] was effective in estimating $\mathrm{FMR}_{\mathrm{ST}}$ to within $6.3 \pm$ $2.1 \%$ of true values in the absence of flipper stroking data (Table 2).

During the shorter migration, flipper stroking frequency was $28538 \pm 422$ strokes $\mathrm{d}^{-1}$ and was best described by the equation:

$$
\mathrm{R}_{\mathrm{ST}}=3164 t^{0.51}\left(\mathrm{r}^{2}=0.33, \mathrm{~F}_{1,11}=5.428, p=0.04\right)
$$

where $R_{S T}$ is flipper stroke rate of actively-swimming seals during the short foraging trip in strokes $\mathrm{d}^{-1}$, and $t$ is time spent at sea in days.
With basal costs [43] removed, the impact of each flipper stroke on locomotion costs was approximately 0.24 $\pm 0.04 \mathrm{~J} \mathrm{~kg}^{-1}$.

\section{Long trip (pregnancy)}

FMRs during the long trip $\left(69.4 \pm 3.0 \mathrm{~kJ} \mathrm{~kg}^{-1}\right.$ day $\left.^{-1}\right)$ were significantly lower than during the short trip (Welch two-sample $t$-test, $\mathrm{t}=6.1972, \mathrm{df}=8.232, \quad p<0.001$ ), therefore, we reject the null hypothesis that there is no difference in FMRs between migrations. Further, Cohen's effect-size value and correlation $(d=3.2335, r=0.8504)$ indicate a large effect with high practical significance and a strong correlation between migration and FMR. The largest seals expended the least amount of energy on a mass-specific basis during the longer foraging migration (Fig. 2), and compared to seals during the short migration, pregnant seals had lower mass-specific FMRs for a given size, falling below Kleiber predictions of mammalian basal metabolic rates (Table 1, Fig. 3). Mass-specific FMR in this group could best be described by the equation:

$$
\begin{aligned}
\mathrm{FMR}_{\mathrm{LT}} & =5818 \mathrm{M}^{-0.74}\left(\mathrm{r}^{2}=0.65, \mathrm{~F}_{1,4}\right. \\
& =7.568, p=0.05)
\end{aligned}
$$

where $\mathrm{FMR}_{\mathrm{LT}}$ is field metabolic rate during the long trip in $\mathrm{kJ} \mathrm{kg}^{-1} \mathrm{~d}^{-1}$, and $\mathrm{M}$ is mass in $\mathrm{kg}$. Despite its low 
predictive $\left(\mathrm{r}^{2}\right)$ value, eq. [4] was effective in estimating $\mathrm{FMR}_{\mathrm{LT}}$ to within $4.3 \pm 2.8 \%$ of true values in the absence of flipper stroking data (Table 2).

Flipper stroking frequency was $24 \%$ lower during the long migration (21 $568 \pm 947$ strokes $\mathrm{d}^{-1}$ ) than during the short migration, and larger, pregnant seals stroked less (Table 1). Stroking frequency for seals during the long migration was best described by the equation:

$$
\begin{aligned}
\mathrm{R}_{\mathrm{LT}} & =2368645 \mathrm{M}^{-0.79}\left(\mathrm{r}^{2}=0.68, \mathrm{~F}_{1,4}\right. \\
& =11.56, p=0.03)
\end{aligned}
$$

where $R_{\mathrm{LT}}$ is flipper stroke rate of seals during the long foraging trip in strokes $\mathrm{d}^{-1}$, and $\mathrm{M}$ is mass in $\mathrm{kg}$. We were unable to detect an effect of time spent at sea on FMR or flipper stroking frequency during the long trip.

With basal costs removed, the impact of each flipper stroke on locomotion costs was calculated as $-0.50 \pm$ $0.11 \mathrm{~J} \mathrm{~kg}^{-1}$, indicating an overestimation of basal costs in this group.

\section{Foraging success and energy budgets}

Mass gain, energy gain, and other indicators of foraging success for each seal are listed in Table 3. This information was used in combination with energy expenditures calculated above to determine the overall energy budget of each seal during her respective foraging migration (Fig. 4).

\section{Short trip}

During the shorter migration, approximately $31.4 \pm 2.1 \%$ of total energy intake was allocated towards somatic mass gain (adipose + lean tissue), while $38.1 \pm 7.2 \%$ and $3.8 \pm 0.1 \%$ of total energy intake was devoted to basal metabolism and locomotion, respectively (Fig. 4). The remainder of total energy intake was lost as HIF and in the formation of urine and feces, as described in the methods.

\section{Long trip (pregnancy)}

During the longer migration, approximately $30.8 \pm 1 \%$ of total energy intake was allocated towards somatic mass gain (adipose + lean tissue), which was not significantly different from the shorter migration (GLS with fixed variance structure, $\mathrm{F}_{2,16}=-1.155, p=0.88$ ). Similarly, we were unable to detect an effect of mass on the proportion of total energy intake allocated towards somatic mass gain during either migration (GLS with fixed variance structure, $\mathrm{F}_{2,16}=-1.179, p=0.26$ ).

In contrast to somatic mass gain, the proportion of total energy intake utilized in locomotion was significantly lower $(-7.7 \pm 0.02 \%)$ during the longer migration (GLS with fixed variance structure, $\mathrm{F}_{2,16}=28.56, p<$ $0.001)$. We were unable to detect an effect of body mass on this proportion $\left(\mathrm{F}_{2,16}=0.126, p=0.64\right)$. Again, it is likely that locomotion results below zero are an artifact of inflated BMR estimates in this group. If we instead assume the energetic cost of each flipper stroke is the same for seals during both migrations, and because seals stroke $24 \%$ less during the long migration (Fig. 5), we can estimate the actual proportion of total energy intake allocated towards locomotion in this group to be about $2.9 \%$. Fetal gestation costs consumed approximately 3.5 $\pm 0.3 \%$ of total energy ingested during the long trip.

To "balance the budget" during the long migration, energy must have been shuttled away from metabolic overhead, which would require an approximately $22 \pm$ $2.7 \%$ reduction in BMR to achieve (Fig. 4). This reduction gives BMR a proportional contribution to overall costs that is comparable with that seen in the short-trip seals because mass-specific energy expenditure was lower in long-trip seals as described above. Thus, approximately $36.3 \pm 1.1 \%$ of total ingested energy was allocated towards BMR during the long trip instead of the approximately $47 \%$ estimated before reduction in metabolic overhead was accounted for.

\section{Energy requirements}

Seals in this study ingested an average of $5.02 \times 10^{3}$ $( \pm 261)$ and $12.4 \times 10^{3}( \pm 645)$ MJ during the course of the short and long migrations, respectively (Fig. 4). For both groups, this ingestion rate is the equivalent of approximately 64-141 MJ per day spent foraging at sea ( $56 \pm 2$ and $126 \pm 10$ days during the short and long migrations, respectively), or 980-2200 kJ per foraging dive $\left(3.74 \times 10^{3} \pm 161\right.$ and $8.36 \times 10^{3} \pm 581$ total foraging dives during the short and long migrations, respectively).

\section{Seals with added drag}

Seals swimming with added drag during the short migration (hereafter referred to as "drag seals," $N=3$ ) experienced a $14.5 \%$ increase in FMR (Table 1, Fig. 2), resulting in half the mass gain of other short-trip seals swimming without the acoustic tags (hereafter referred to as "normally-swimming seals") (Table 3). However, this should be interpreted as a conservative estimate of energy expenditure in the drag group as we have assumed stroking costs similar to those of normallyswimming seals. Two of the drag seals were at sea for as long as normally-swimming short-trip seals (74.6 days, S.D. $= \pm 4.8$ days), but with substantially lower mass gain . The remaining drag seal (1234) spent 100.8 days at sea, with below normal mass gain results intermediate between those of the other two drag seals (Table 3).

Low mass gain in the drag seals resulted from the allocation of a disproportionately large amount of energy intake toward locomotion costs. Drag seals spent more than four times as much energy on locomotion (16.7 \pm 
$0.02 \%$ of total energy intake) as the normallyswimming, short-trip seals reported above, with a resultant one-third of the energy spent on somatic mass gain $(11.7 \pm 0.03 \%$ of total energy intake) (Fig. 4). This was likely due to increased locomotion costs associated with overcoming the added hydrodynamic drag during diving and swimming, which is supported by the increased flipper stroking frequency demonstrated by the drag seals in comparison to normally-swimming, short-trip seals (22\% more strokes per day) (Fig. 5). The limited variation in stroking frequency for drag seals compared to the other groups suggests these individuals may have been pushing up against a biomechanically-constrained limit to swimming effort while foraging.

\section{Discussion}

\section{Energy economy and the effects of pregnancy}

The energy requirements of adult female northern elephant seals are much lower than those described for most other mammalian carnivores, and particularly so during pregnancy. Mammalian carnivores typically have higher energy needs than other terrestrial mammals, and thus require large food supplies to fuel fast metabolisms $[9,24]$. As such, FMRs tend to run high in this group, ranging from 1.99 - 4.65 times Kleiber [43] predictions of BMR in terrestrial mammalian carnivores [summarized in 25, 26], and from 4.88-6.44 Kleiber predictions in marine mammal carnivores [27, 28] [although see 29, 30]. However, more recent studies on the diving metabolism (DMR) of adult phocid seals indicate they are more efficient than other marine carnivores [44, 33]. For example, Weddell seals diving in the wild for as long as the average elephant seal in our study $(21.5 \mathrm{~min})$ operated at 1.7 Kleiber [44].

During the 2.5-month post-breeding foraging trip, adult elephant seals were able to recover the energy reserves lost during lactation by operating at 1.36 (range = 1.21-1.48) Kleiber predictions of basal metabolism, indicating a high degree of metabolic efficiency in this species (Table 1, Fig. 3). These results are in line with results from previous studies on both free-swimming $[23,31]$ and captive [32-34, 28] elephant seals where large oxygen storage capacities combined with a high tolerance for hypoxia indicated these animals should be able to operate aerobically at 0.9-1.9 times Kleiber predictions from as early as 2 months old. While measurements in these examples were from young animals, recent studies on other phocids in captivity were unable to detect a difference between juvenile and adult DMRs [grey seals: 33] or BMRs [harp, harbor and ringed seals: 34]. As this could be an artifact of captivity, these results should be interpreted with caution; nonetheless, they do suggest that using measurements of metabolism in juveniles to ground truth our calculations for adults is a valid approach.

The degree of metabolic efficiency was correlated with body size and reproductive status, with the largest animals having the lowest mass-specific FMRs during pregnancy (Fig. 2). During the 7.5-month post-molt foraging trip, female seals were able to fuel gestation costs and a $90 \%$ (S.D. $= \pm 21 \%$ ) increase in body mass by operating at FMRs approaching or falling below Kleiber predictions of basal metabolism (Fig. 3). In most mammals, pregnancy elevates metabolism [35, 36]; however, like other phocids, elephant seals fast during the breeding season and therefore must fuel lactation costs using onboard fuel reserves accumulated during the long foraging trip. Suppressed metabolism and increased fuel economy during pregnancy is likely a pre-pupping fattening strategy, and while it has been measured in resting, captive harp seals [31, 37, 34], grey seals [32], harbor and ringed seals [34], our study is the first to demonstrate suppressed metabolism during pregnancy in actively foraging, wild seals during their months-long migrations.

Our results provide empirical support for hypotheses that have inferred hypometabolism based on diving behavior, as elephant seals regularly dive for longer than their calculated aerobic dive limit [38] without engaging in a long recovery period afterward. These authors suggest that traditional predictions of diving metabolic rates based on allometric equations must be overestimates - instead, elephant seals must be hypometabolic while diving, and particularly so during the long foraging trip [39-42]. Compared to similarly-sized short-trip females,who are themselves operating at remarkably low metabolic rates (this study), longtrip seals were shown to suppress their field metabolism by a further $22 \%$ (range $=15 \%$ in smaller seals to $32 \%$ in the largest), to rates below those predicted to be necessary to support even basic maintenance metabolism (Fig. 3). Boyd [12] predicted a similar trend for marine mammals using first principles, arguing that locomotion should be more efficient, and thermoregulation costs lower or non-existent, in larger aquatic animals.

The argument for a more severe degree of hypometabolism in northern elephant seals compared to other breath-hold divers is thus well-supported, and promotes the extreme at-sea lifestyle of this species. As part of the oxygen-conserving dive response, breath-hold triggers a reduction in metabolic rate in all mammals, and more markedly so in diving species [43, 44]. Extreme hypometabolism allows elephant seals to spend upwards of $95 \%$ of their time at sea in breath-hold, exploiting depths down to $1600 \mathrm{~m}$ for up to $2 \mathrm{~h}$, entirely aerobically. In contrast, other extreme divers such as Cuvier's and Blainville's beaked whales will regularly spend 60-90 min recovering between deep dives [45], suggesting that 
Table 1 Summary of energy costs for northern elephant seals instrumented with accelerometers $(N=22)$

\begin{tabular}{|c|c|c|c|c|c|c|c|}
\hline Migration & Seal & Average Mass (kg) & DAS (TDR) & Stroke Rate $\left(\mathrm{d}^{-1}\right)$ & FMR $\left(\mathrm{kJ} \mathrm{kg}^{-1} \mathrm{~d}^{-1}\right)$ & Kleiber & Total E Spent (MJ) \\
\hline \multirow[t]{13}{*}{ ST: Short trip } & U954 & 297 & 71.9 & 27840 & 90.7 & 1.28 & 1934 \\
\hline & U605 & 308 & 69.5 & 28548 & 91.1 & 1.30 & 1946 \\
\hline & U627 & 333 & 86.6 & 29972 & 97.4 & 1.42 & 2810 \\
\hline & T911 & 343 & 72.5 & 27423 & 85.8 & 1.26 & 2131 \\
\hline & 1015 & 354 & 74.1 & 29100 & 92.9 & 1.37 & 2437 \\
\hline & X851 & 372 & 71.2 & 28674 & 94.6 & 1.42 & 2506 \\
\hline & T35 & 384 & 75.6 & 30385 & 96.6 & 1.46 & 2800 \\
\hline & N796A & 391 & 72.8 & 28534 & 92.7 & 1.41 & 2640 \\
\hline & R541 & 392 & 77.7 & 29595 & 97.5 & 1.48 & 2973 \\
\hline & 1733 & 406 & 78.2 & 27925 & 83.2 & 1.27 & 2642 \\
\hline & N796B & 407 & 71.8 & 28818 & 92.4 & 1.42 & 2699 \\
\hline & W1095 & 433 & 79.5 & 29785 & 91.8 & 1.43 & 3163 \\
\hline & R382 & 466 & 69.3 & 24397 & 76.1 & 1.21 & 2459 \\
\hline \multirow[t]{6}{*}{ LT: Long trip (pregnancy) } & U458 & 341 & 222.1 & 22825 & 72.9 & 1.07 & 5519 \\
\hline & T730 & 343 & 218.8 & 23731 & 75.0 & 1.10 & 5623 \\
\hline & X106 & 379 & 230.8 & 21770 & 70.5 & 1.06 & 6170 \\
\hline & U754 & 395 & 221.1 & 23579 & 77.1 & 1.17 & 6727 \\
\hline & 2036 & 445 & 224.5 & 19335 & 62.9 & 0.99 & 6287 \\
\hline & U203 & 450 & 224.5 & 18165 & 57.9 & 0.91 & 5841 \\
\hline \multirow[t]{3}{*}{ DG: Short trip (added drag) } & 1234 & 374 & 100.8 & 34822 & 104.5 & 1.57 & 3932 \\
\hline & M780 & 378 & 78.1 & 34299 & 103.2 & 1.55 & 3044 \\
\hline & 2370 & 433 & 76.6 & 35669 & 105.1 & 1.64 & 3484 \\
\hline Mean ST & & 376 & 75 & 28538 & 91.0 & 1.36 & 2549 \\
\hline (S.E.) & & $(13.5)$ & $(1.3)$ & $(422)$ & $(1.7)$ & $(0.02)$ & (103) \\
\hline Mean LT & & 392 & 224 & 21568 & 69.4 & 1.05 & 6028 \\
\hline (S.E.) & & $(19.5)$ & $(1.7)$ & (947) & (3.0) & $(0.04)$ & (186) \\
\hline Mean DG & & 395 & 85 & 34930 & 104.2 & 1.58 & 3487 \\
\hline (S.E.) & & (19.1) & (7.8) & (399) & $(0.6)$ & $(0.03)$ & (256) \\
\hline
\end{tabular}

"Average Mass" is the seal's mass averaged across the entire migration, based on her weight at the beginning and end of the trip. "Stroke Rate" refers to the number of flipper strokes per day averaged across the migration, and "FMR" refers to estimated field metabolic rates based on the total number of flipper strokes and a cost-per-stroke of $2.58 \mathrm{~J} \mathrm{~kg}^{-1}$ [23] plus HIF costs. "FMR (Kleiber)" is a multiplier of Kleiber [43] predictions of mammalian basal metabolic rate. "Total E Spent" is the total amount of energy spent during foraging. See text for equations

anaerobic metabolism is at least partly fuelling dives to extreme depths. These species have likely evolved adaptations that allow them to tolerate and process large amounts of lactic acid, whereas elephant seals seem to have evolved the ability to mostly just avoid it altogether with a more pronounced degree of hypometabolism. Other slow-moving, deep-diving marine mammals with short surface intervals, such as sperm whales [46], might also be expected to be hypometabolic.

In our study, lower at-sea FMRs in seals during pregnancy were also the result of reduced flipper stroking frequencies during active swimming (Fig. 3). For both groups, most flipper stroking occurs during the ascent phase of the dive cycle (Fig. 6), when seals must work against their negative buoyancy at depth to reach the surface $[47,48]$.
As the foraging migrations progress, seals are able to store more fat, becoming less negatively buoyant [16, 49], and we would expect an inverse relationship between buoyancy and the number of flipper strokes required to surface [5052]. As seals generally gain more adipose tissue during the long trip (Table 3) a reduction in the number of flipper strokes necessary to surface compared to their short-trip counterparts is not surprising. With each flipper stroke having a predictable effect on overall energy costs, this reduced stroking frequency results in approximately $1700 \pm$ $90 \mathrm{MJ}$ in energy savings across the long foraging migration.

\section{Energy budgets}

Despite the 5-month difference in trip duration, partitioning of ingested energy was remarkably similar across 
Table 2 Comparison of different metrics for estimating at-sea FMRs of northern elephant seals

\begin{tabular}{|c|c|c|c|c|}
\hline Migration & Seal & FMR ("True") kJ kg ${ }^{-1} \mathrm{~d}^{-1}$ & FMR (Alternate) $\mathrm{kJ} \mathrm{kg}^{-1} \mathrm{~d}^{-1}$ & FMR Error: (Alternate - "True") \\
\hline \multirow[t]{13}{*}{ ST: Short trip } & U954 & 90.7 & 93.6 & 3.03 \\
\hline & U605 & 91.1 & 91.2 & 0.14 \\
\hline & U627 & 97.4 & 99.8 & 2.42 \\
\hline & T911 & 85.8 & 91.2 & 5.90 \\
\hline & 1015 & 92.9 & 91.4 & -1.62 \\
\hline & X851 & 94.6 & 88.9 & -6.48 \\
\hline & T35 & 96.6 & 90.8 & -6.35 \\
\hline & N796A & 92.7 & 87.2 & -6.35 \\
\hline & R541 & 97.5 & 91.6 & -6.42 \\
\hline & 1733 & 83.2 & 91.2 & 8.78 \\
\hline & N796B & 92.4 & 83.6 & -10.52 \\
\hline & W1095 & 91.8 & 79.6 & -15.34 \\
\hline & R382 & 76.1 & 83.5 & 8.79 \\
\hline \multirow[t]{6}{*}{ LT: Long trip (pregnancy) } & U458 & 72.9 & 76.3 & 4.42 \\
\hline & $\mathrm{T} 730$ & 75.0 & 76.0 & 1.28 \\
\hline & X106 & 70.5 & 70.5 & -0.08 \\
\hline & U754 & 77.1 & 68.4 & -12.71 \\
\hline & 2036 & 62.9 & 62.6 & -0.59 \\
\hline & U203 & 57.9 & 62.1 & 6.80 \\
\hline \multirow[t]{3}{*}{ DG: Short trip (added drag) } & 1234 & 104.5 & 104.7 & 0.22 \\
\hline & M780 & 103.2 & 92.5 & -11.52 \\
\hline & 2370 & 105.1 & 83.3 & -26.23 \\
\hline Mean ST & & 91.0 & 89.5 & 6.3 \\
\hline (S.E.) & & & & $(2.1)$ \\
\hline Mean LT & & 69.4 & 69.3 & 4.3 \\
\hline (S.E.) & & & & $(2.8)$ \\
\hline Mean DG & & 104.2 & 93.5 & 12.7 \\
\hline (S.E.) & & & & $(7.7)$ \\
\hline
\end{tabular}

FMR ("True") is the field metabolic rate based on total number of measured flipper strokes and individual stroke costs, and FMR (Alternate) is based on the alternate metric with the strongest predictive relationship: mass and days at sea for ST and DG seals (eq. [2] in text), and mass for LT seals (eq. [4] in text). Error column represents percent difference in FMRs estimated using the different approaches, with mean ( \pm SE) absolute error indicated

the two migrations. During the short trip, locomotion costs were low, constituting approximately $4 \%$ of overall energy expenditure, which is somewhat lower than the $10 \%$ reported for similarly-sized, freely-diving Weddell seals [calculated from eq.[3] in 44]. In contrast, locomotion costs of seals during the long migration were calculated as being negligible; however, this is likely the result of our assumption of an unvarying BMR equal to Kleiber predictions in these seals. As discussed above, there are several lines of evidence supporting the idea that 'basal' metabolism is less static in phocid seals than in terrestrial mammals, and that hypometabolism is common during pregnancy $[31,37,32]$. It is likely that this hypometabolism is the driver of reduced at-sea FMRs in pregnant elephant seal females rather than zero or negative locomotion costs. The physiological mechanism behind suppression is unclear, but may be a conditioning effect of chronic oxidative stress with increased time spent at sea in elephant seals [41, 53]. If locomotion costs on a per-stroke basis are instead assumed to be the same during both migrations, basal maintenance costs in pregnant elephant seals must be reduced by approximately $22 \%$ (range $=14-33 \%$ ) of Kleiber predictions to "balance the budget" in terms of work costs (Fig. 4). This compares to a reported $30 \%$ and $27 \%$ reduction in the resting metabolism of captive, pregnant harp and grey seals, respectively [31, 32].

The overall net energy available to fuel production was highly variable for both migrations, with seals who were initially fatter tending to acquire more prey-energy, gain more weight, store more lipid, and birth larger pups (Table 3), even after controlling for maternal age. For 


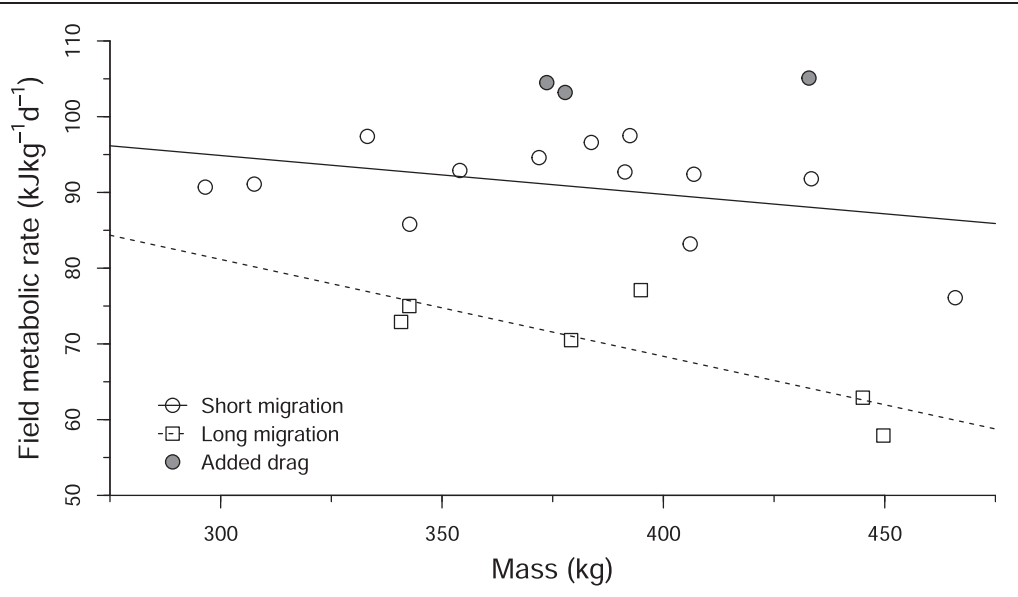

Fig. 2 Mass-specific field metabolic rates of northern elephant seals (Mirounga angustirostris) based on total number of flipper strokes executed during their foraging migrations, as a function of mass. Filled circles indicate seals carrying added drag during their short migrations. See text for equations

example, seal 2036 increased her mass by $118 \%$ compared to $66 \%$ for T730, and gave birth to a $50-\mathrm{kg}$ pup (versus $31 \mathrm{~kg}$ ); however, 2036 was fatter than T730 at the beginning of her long migration, but had a lower total number of flipper strokes despite a longer trip duration (Table 1). We postulate a positive feedback loop whereby fatter seals are less negatively buoyant during the course of the trip, reducing locomotion costs as described above, freeing up more energy to devote towards both somatic growth (fattening) and fetal production. As adiposity increases and seals approach energeticallyoptimal buoyancy levels where locomotion costs are lowest [49], it stands that more energy would be available for allocation towards the growing fetus.

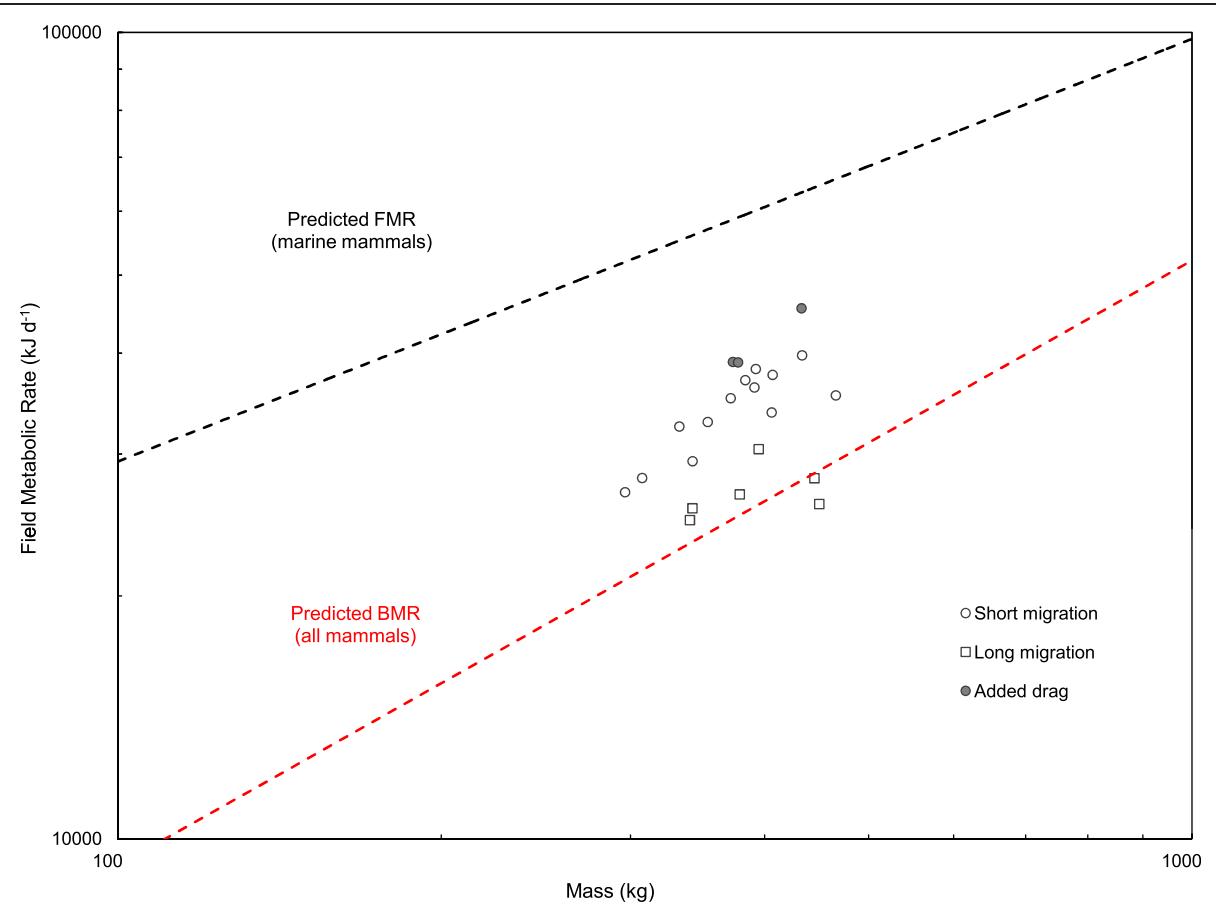

Fig. 3 Field metabolic rates of northern elephant seals (Mirounga angustirostris) compared to Kleiber [43] predictions of mammalian basal metabolic rate (BMR) (dashed red line) and Boyd [12] predictions of marine mammal field metabolic rate (FMR) (dashed grey line), as a function of mass. Compared to seals during their short migration, seals of similar average body mass had $23 \%$ lower FMRs during the long migration according to the equation $\mathrm{FMR}^{*}{ }_{\mathrm{LT}}=5818 \mathrm{M}^{0.26}$ 
Table 3 Summary of mass and energy gains for elephant seals instrumented with accelerometers $(N=22)$

\begin{tabular}{|c|c|c|c|c|c|c|}
\hline Migration & Seal & Mass Gain (\%) & Adipose Gain (kg) & Lean Gain (kg) & Net E Gain (MJ) & Gross E Gain (MJ) \\
\hline \multirow[t]{13}{*}{ ST: Short trip } & U954 & 31.7 & 35.3 & 45.8 & 1539 & 4185 \\
\hline & U605 & 27.8 & 27.1 & 48.0 & 1266 & 3869 \\
\hline & U627 & 43.7 & 49.2 & 70.3 & 2187 & 6021 \\
\hline & T911 & 20.3 & 23.6 & 39.7 & 1086 & 3877 \\
\hline & 1015 & 21.9 & 39.4 & 30.6 & 1589 & 4851 \\
\hline & X851 & 31.1 & 54.1 & 45.9 & 2205 & 5676 \\
\hline & T35 & 25.2 & 41.2 & 44.9 & 1742 & 5472 \\
\hline & N796A & 29.5 & 48.6 & 52.0 & 2051 & 5652 \\
\hline & R541 & 37.2 & 61.9 & 61.1 & 2579 & 6688 \\
\hline & 1733 & 11.8 & 4.4 & 40.8 & 413 & 3681 \\
\hline & N796B & 26.9 & 42.8 & 53.7 & 1856 & 5488 \\
\hline & W1095 & 17.9 & 28.1 & 43.2 & 1268 & 5339 \\
\hline & R382 & 15.5 & 27.1 & 40.0 & 1215 & 4426 \\
\hline \multirow[t]{6}{*}{ LT: Long trip (pregnancy) } & U458 & 96.0 & 66.4 & 202.6 & 3635 & 11029 \\
\hline & $\mathrm{T} 730$ & 66.4 & 68.8 & 132.9 & 3280 & 10727 \\
\hline & X106 & 89.5 & 98.5 & 183.9 & 4655 & 13042 \\
\hline & U754 & 103.7 & 121.0 & 188.7 & 5480 & 14707 \\
\hline & 2036 & 117.6 & 87.3 & 292.2 & 4944 & 13531 \\
\hline & U203 & 65.1 & 72.0 & 185.0 & 3721 & 11520 \\
\hline \multirow[t]{3}{*}{ DG: Short trip (added drag) } & 1234 & 11.8 & 18.8 & 22.9 & 810 & 5714 \\
\hline & M780 & 8.9 & 16.7 & 15.5 & 690 & 4499 \\
\hline & 2370 & 16.6 & -0.4 & 41.7 & 252 & 4501 \\
\hline Mean ST & & 26.2 & 37.1 & 47.4 & 1615 & 5017 \\
\hline (S.E.) & & $(2.5)$ & $(4.2)$ & $(2.8)$ & $(160)$ & (261) \\
\hline Mean LT & & 89.7 & 85.7 & 197.6 & 4286 & 12426 \\
\hline (S.E.) & & (8.5) & (8.7) & $(21.3)$ & (354) & (645) \\
\hline Mean DG & & 12.4 & 11.7 & 26.7 & 584 & 4905 \\
\hline (S.E.) & & $(2.2)$ & (6.1) & (7.8) & (170) & (404) \\
\hline
\end{tabular}

Mass Gain (\%) is the increase in mass (post-migration) as a percentage of initial body mass (pre-migration). "Net $\mathrm{E}$ Gained" is the net energy gained during the foraging migration, and "Gross E Gained" is gross energy intake from prey before assimilation costs are deducted. For LT seals, all terms include mass or energy gained by both the mother and her gestating pup. See text for equations

\section{Energy requirements}

Seals in this study ingested an average of $5017( \pm 261)$ and $12426( \pm 645)$ MJ during the course of the short and long migrations, respectively (Fig. 4). Our estimate for short-trip seals is in complete agreement with Sakamoto et al.'s [54] estimate using an energy components analysis on the TDR record of one seal. Depending on the energy density of ingested prey items, we estimate that elephant seals in both groups would have needed to capture approximately $2-8 \%$ of their average body mass in prey per day spent foraging, which is in close agreement with the $6.2 \%$ predicted by Le Boeuf et al. [39]. This ingestion rate is the equivalent of $8-32 \mathrm{~kg}$ of prey captured per day spent foraging at sea which is, again, in agreement with Le Boeuf et al.'s [39] estimate of $20 \mathrm{~kg}$ based only on dive behavior. This ingestion rate is also the equivalent of 5-24 prey items per foraging dive, which is in agreement with Naito et al.'s [45] reported average of $14.6($ S.D. $= \pm 3$ ) prey capture attempts per dive. Collectively, these lines of evidence support our stroke-based estimates of at-sea FMRs in adult female northern elephant seals.

\section{Disruption of routine swimming behaviors}

The three seals carrying the experimental acoustic tags ("drag seals") had FMRs elevated $14.5 \%$ above other short-trip seals (Fig. 2), operating at approximately 1.58 $( \pm 0.03)$ Kleiber predictions of basal metabolism (Table 1). This was likely the result of increased locomotion costs, as the experimental tags increased the seal's frontal 


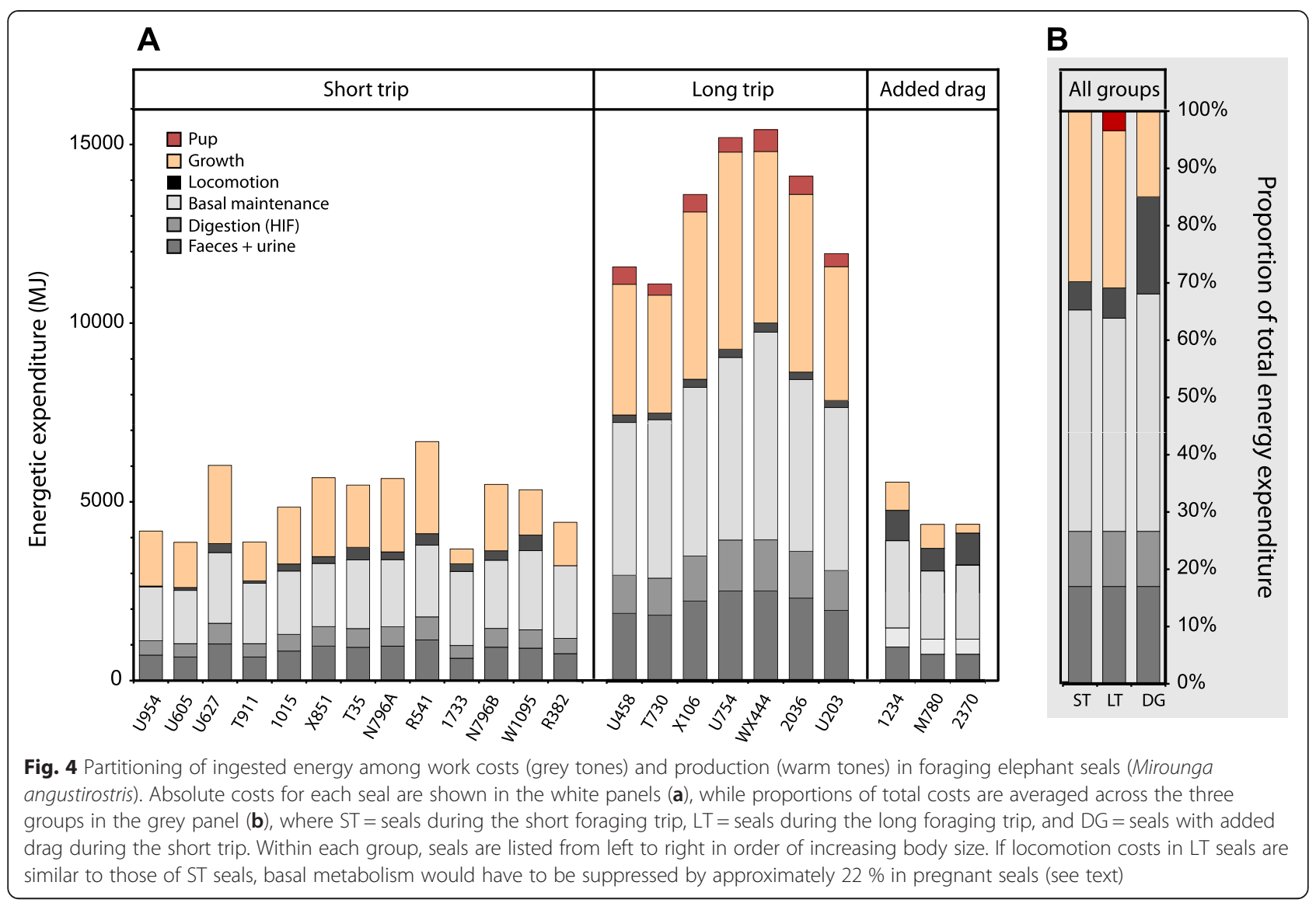

surface area by about $7 \%$, which is large enough to induce increased transport costs in a number of large marine organisms [e.g., 55, 56]. Our results are comparable to what has been seen in other species such as Adelie penguins (Pygoscelis adeliae) where instruments representing an approximately $10 \%$ increase in frontal surface area increased the cost of transport by about $14 \%$ [57]. Increased locomotion costs are illustrated in Fig. 5, with drag seals flipper stroking consistently faster than normally-swimming short-trip and potentially pushing up against a biomechanically constrained maximum rate. With more energy partitioned toward the fuelling of flipper strokes (17\% versus $4 \%$ ), drag seals were able to partition relatively little ingested energy toward somatic mass gain (12\% versus $31 \%$ ) (Fig. 6).

These results suggest that elephant seals fuel their substantial mass gain during foraging migrations by engaging in stereotypic, energy-saving flipper stroking behaviors that keep locomotion costs low, and that increasing these costs can have considerable impacts on foraging success. This may have implications for the ability of elephant seals to adapt to at-sea disturbance, with avoidance behaviors predicted to reduce time spent foraging while increasing time spent in transit - a disruption of routine swimming behaviors that inflates normally-low locomotion costs, thereby reducing the surplus energy available to the seal for partitioning towards mass gain [as in, for example, 58, 59]. We predict that this effect would be exacerbated in pregnant, longtrip seals, which are potentially operating at or near a lower physiological limit to metabolism in order to adequately and rapidly build fuel reserves in support of a very costly lactation period.

\section{Conclusions}

By accounting for each of the costs associated with foraging, we can assess the efforts free-living animals spend acquiring resources, and thus, their overall energy requirements [12, 63]. Although estimates of FMR have been made for fin [60] and minke whales [61], the seals in our study represent the largest carnivores measured empirically. Northern elephant seals have adopted a foraging strategy that utilizes a high degree of extreme energy economy, with FMRs that are (1) 70-80 \% lower than predicted for carnivores of their size [52]; (2) 35$60 \%$ lower than predicted for marine mammals of their size [12]; and (3) 25-40\% lower than what has been measured in freely-diving Weddell seals of similar size, 


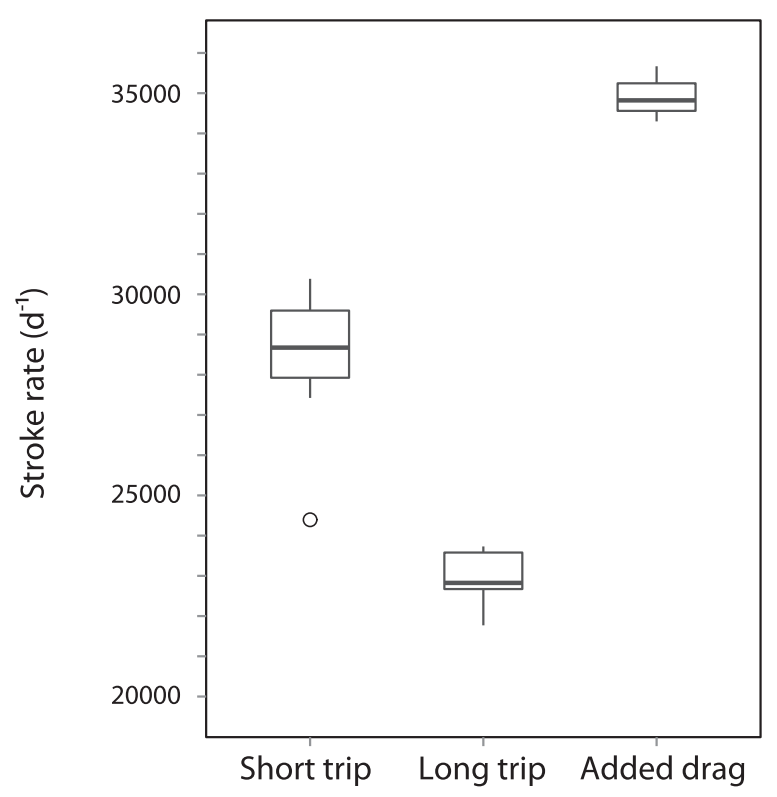

Fig. 5 Flipper stroke rates were higher for northern elephant seals (Mirounga angustirostris) swimming normally during the short foraging trip ( $N$ =13) than during the long foraging trip $(N=6)$. In comparison, seals swimming with added drag during their short trips $(N=3)$ stroked consistently faster than normally swimming seals during the same time (Welch two-sample $t$-test, $\mathrm{t}=-10.9982, \mathrm{df}=7.471, p<0.001$ ). Dark horizontal bars represent median $\left(50^{\text {th }}\right.$ percentile) values while the lower and upper limits of the boxes represent the $25^{\text {th }}$ and $75^{\text {th }}$ percentiles, respectively. Whiskers correspond to the 1.5 interquartile range, and points represent outliers

and for similar diving durations [44]. Body mass was the most important determinant of FMR in our study, with a particularly dramatic effect of pregnancy such that, in the largest long-trip seals, Kleiber predictions of mammalian basal metabolism actually overestimated total atsea energy expenditure. Pregnant seals were able to suppress their FMRs as body condition improved, thereby reducing the frequency of flipper strokes, and also by further reducing basal maintenance metabolism by an additional $22 \%$ compared to non-pregnant seals during the short trip. The very efficient FMRs of seals during both the short (1.4x Kleiber) and long migrations (1.1x Kleiber) likely represent fattening strategies in preparation for the high energy demands of a month-long fast while molting and nursing, respectively. In contrast to normally-swimming seals, those instrumented with bulky, non-streamlined acoustic tags experienced elevated FMRs as a result of increased locomotion costs, significantly reducing foraging success and the net energy available for mass gain in these seals. Collectively, these results suggest that elephant seals keep overall energy requirements, and thus prey requirements, relatively low during their foraging migrations by engaging in adaptively stereotyped flipper stroking behaviors that minimize locomotion costs and, most likely, maintenance metabolism while diving. Minimization of these work costs frees up more of the energy ingested from prey items for fuelling of production, namely, accumulation of energy reserves for support of maintenance metabolism while fasting on land, and for pregnant seals, gestation and lactation.

\section{Methods}

\section{Study animals}

This project was approved by the Institutional Animal Care and Use Committee at the University of California in Santa Cruz. 21 adult female elephant seals were instrumented at their breeding colony in the Año Nuevo State Reserve, California, USA ( $\left.37^{\circ} 5^{\prime} \mathrm{N}, 122^{\circ} 16^{\prime} \mathrm{W}\right)$ from 2009 - 2013. We chemically immobilized the seals for instrument attachment and recovery using established protocols that minimize handling time and stress [21]. Apparently healthy seals were selected and 15 were of known age ranging from 5 to 12 years old. N796 was instrumented in both 2009 and 2010, and we present each track separately. The study included both annual foraging migrations: the short, post-breeding migration (February through April; $N=16$ ) and the long, postmolting, gestational migration (June through December; $N=7$ ).

\section{Flipper stroking data}

Seals were instrumented with a time-depth recorder (TDR) (Wildlife Computers MK9, MK10; or Lotek, St. John's, NL, Canada: 2310) and a tri-axis accelerometer/ magnetometer (Wildlife Computers MK10-style prototype, 16-hz sampling rate, $N=9$, sample years 2009-2011; or Little Leonardo ORI2000-D3GT, 32-hz sampling rate, 
$N=13$, sample years 2011-2013) for collection of at-sea diving and flipper stroking data, respectively. The raw time-series of accelerometry measurements were truncated according to departure/arrival times identified using the diving record, and flipper strokes isolated using one of two custom-written programs in Igor Pro 6.36 (WaveMetrics, Inc., USA), depending on the instrument model used. In brief, side-to-side flipper movements were detected as fluctuations in the transverse axis - "swaying" acceleration - and the static (positional) component was separated from the dynamic (movement) component using a $1 \mathrm{~Hz}$ low-pass filter [62]. The remaining peaks and troughs in the dynamic swaying acceleration with amplitudes greater than $1 \mathrm{~m} \mathrm{~s}^{-2}$ were considered to be individual flipper strokes and were used in analyses.

Output from the Wildlife Computer instruments included raw acceleration data, and a user-written algorithm was used to identify and count individual flipper strokes [23]. In contrast, with the exception of $12 \mathrm{~h}$ per record, raw data were processed on-board the Little Leonardo instruments with stroke rate calculated using a built-in algorithm. To make comparisons between algorithms, we processed each seal's $12 \mathrm{~h}$ of raw Little Leonardo accelerometry data through our user-written algorithm and used the percent discrepancy between stroke counts to correct the total number of counts output by the Little Leonardo algorithm. In most cases, the total number of strokes counted by the two algorithms were within $10 \%$ of each other; however, in 2 cases, the discrepancy was greater than $10 \%$ (14\% for T35, $20 \%$ for T730). For this reason, and for consistency, we used corrected counts from the Little Leonardo instruments, rather than the processed output from the instruments, in analyses.

As part of a separate study, three seals were additionally outfitted with prototype acoustic tags, for testing of their viability in future studies. The tags were large, not streamlined, heavy, and were as follows: cylindrical tags (537.0 x $117.4 \mathrm{~mm}$, cross-sectional area $108.3 \mathrm{~cm}^{2}$, volume $5447 \mathrm{ml}$, mass in air $7500 \mathrm{~g}$, mass in water $2417 \mathrm{~g}$ ) attached along the midline of the seal's back, with the forward leading edge at the position of the seals' maximum girth. The tags were attached using two positively buoyant foam block mounts (each cross-sectional area $28.2 \mathrm{~cm}^{2}$, mass in water $1151 \mathrm{~g}$ ), hose clamp screw (cross-sectional area $2 \mathrm{~cm}^{2}$ ), and VHF transmitter (cross-sectional area $7.7 \mathrm{~cm}^{2}$ ) for a total cross-sectional area of approximately $174.2 \mathrm{~cm}^{2}$ that corresponds to approximately $7 \%$ of the seals' cross-sectional area (ca. $2501.9 \mathrm{~cm}^{2}$ ), and mass in water of $1266 \mathrm{~g}$.

The tags were not deployed with the intention of affecting the foraging success of the animals, but upon recovery these seals were undersized and clearly nutritionally stressed, probably due to the added hydrodynamic drag imposed on the animals by the bulky, non-streamlined instruments. We include these individuals in our analyses here to determine how foraging success and efficiency are affected by disturbance to routine swimming behaviors via increased locomotory costs.

\section{Energetics data}

The surplus energy available to a seal for production of new tissue is a function of the difference between gross food energy ingested at sea and energy lost or expended while foraging. In our study animals, production of new tissue refers to the replenishment of spent energy reserves as both adipose and lean tissue gain, and the gestation of a fetus. Production is therefore defined here as the total mass gained from somatic and fetal growth, and can be described by the equation:

$$
\begin{array}{r}
\mathrm{E}_{\text {MASSGAIN (somatic }+ \text { fetal })}=\mathrm{E}_{\text {INGESTED }}-\mathrm{E}(\text { Feces }+ \text { Urine } \\
+ \text { Digestion }+ \text { Maintenance }+ \text { Locomotion })
\end{array}
$$

where some energy from ingested prey items is lost in the production and excretion of feces and urine, and some energy is expended to fuel digestion costs [63, 64], basal maintenance metabolism and locomotion. Collectively, energy expended for digestion, maintenance and locomotion represent the animal's field metabolic rate (FMR). We do not include heat lost for thermoregulation as a cost as it has been argued [12,65] and demonstrated [66] that heat loss should not be an issue for marine mammals of this size.

To estimate surplus energy gained from foraging ( $E_{\text {MASSGAIN (somatic + fetal) }}$ ), we measured the mass of each seal at the beginning and end of each trip by suspension in a canvas sling from a tripod using a DynaLink scale $(1,000 \pm 1 \mathrm{~kg})$. Mass of adult females at departure and upon arrival was corrected for any time spent on land after instrument attachment or before instrument retrieval, respectively, using an equation derived from serial mass measurements of fasting seals [67]. During the breeding season, when female seals return from their long, post-molt, gestational migrations, the mass of the pup was added to that of the mother five days post-parturition. Waiting a conservative 5 days to handle the newborn pup is part of standard protocol with this species, in order to allow adequate time for maternal contact and bonding (e.g., [68]). Adipose and lean tissue gain was estimated from mass change and body composition, assuming that the five-day-old pup was $13 \%$ adipose tissue [22]. Energy gain was estimated assuming that adipose tissue was $90 \%$ lipid, and lean tissue was $27 \%$ protein with a gross energy content of $39.33 \mathrm{~kJ} \mathrm{~g}^{-1}$ for lipids and $23.5 \mathrm{~kJ} \mathrm{~g}^{-1}$ for protein [22]. Additional gestation costs associated with maternal 

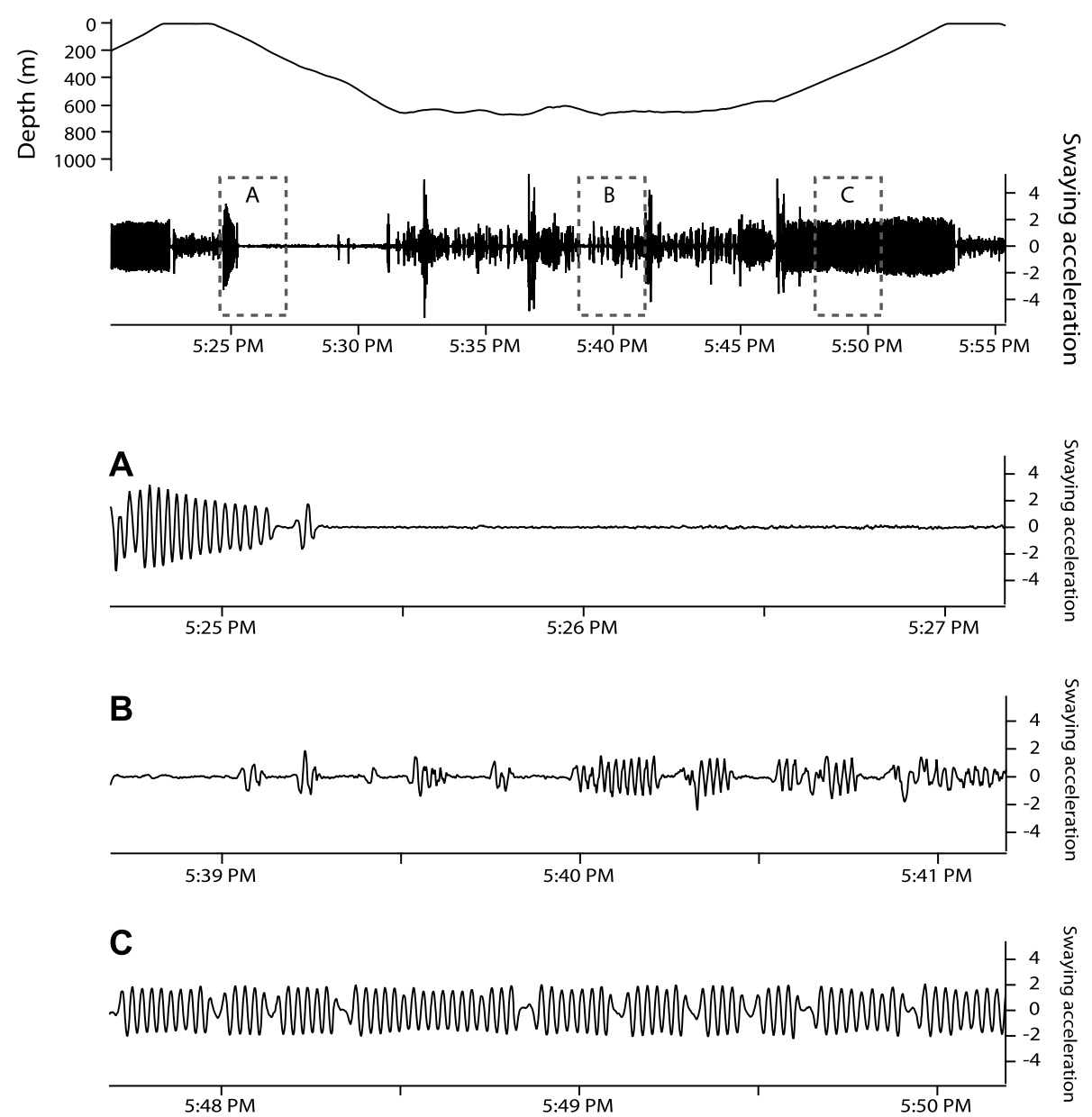

Fig. 6 Flipper stroking of northern elephant seals (Mirounga angustirostris) follows a predictable pattern along the course of each dive. The top panel shows one foraging dive during the short migration of seal X851, where depth is shown with corresponding swaying acceleration. Grey boxes outline approximately 2.5-min segments of flipper stroking, each representing one of the three main phases of a dive cycle: (a) descent, (b) foraging at depth, and (c) ascent. Note the consistent, high-frequency flipper stroking occurring during ascent, when elephant seals are working against their negative buoyancy at depth in order to surface

metabolism were assumed to be negligible based on previous research on other capitally breeding phocids [69, 70], and so were not added to the energy budget of seals in this group.

To estimate energy expenditure (FMR) during the foraging migrations, we used an equation that predicts total FMR from the total number of swim strokes in freeswimming, non-reproductive, fasting seals [FMR ( $\mathrm{kg}$ $\left.{ }^{-1}\right)=2.58 \mathrm{Sn}$, where $\mathrm{Sn}$ is the number of flipper strokes [23]]. This equation was derived from seals younger than the ones in this study, requiring us to rely on the assumption that juvenile and adult animals have similar stroke costs. This might be unrealistic as juvenile mammals often have elevated mass-specific metabolisms relative to adults as a result of increased growth costs. If this were the case, our FMR estimates for adults would be too high. However, Maresh et al. [23] were unable to detect significant relationships between body size or age and stroke costs, although this could have been due to small sample size and lack of statistical power. On the other hand, multiple studies have been unable to detect differences between juvenile and adult metabolic rates in captive phocids [71, 72], indicating that our assumption of similar stroking costs in juvenile and adult elephant seals is reasonable. We consider the sensitivity of our FMR calculations to uncertainty in stroke costs in the Additional file 1.

As FMR represents the sum of all component costs except $E_{\text {feces }}$ and $E_{\text {urine, }}$, (i.e., $F M R=E($ Digestion + Maintenance + Locomotion) from eq.[1]), we estimated each separate cost and its relative contribution to total FMR using values and equations from previous studies (described below). To account for energy lost in via feces and urine, we used a value averaged across multiple studies on phocid seals $[63,73,74]$ whereby approximately $83 \%$ of gross energy consumed from an average 
fish diet is usable as metabolizable energy. This value for assimilation efficiency is in line with studies on other pinnipeds where metabolizable energy was shown to range from between 78.3-91.6\%, depending on the diet [75]. To account for digestion costs (the heat increment of feeding (HIF)), we used the estimate of $11.6 \%$ of metabolizable energy measured in juvenile elephant seals (range $=6.4-18 \%$ ) [76]. This value is in close agreement with other studies of HIF in marine mammals: $10-13 \%$ in sea otters [77], 10-17\% in harp seals [78, 79], and $5.5 \%$ in harbor seals [80].

Basal metabolic rate (BMR) has not been measured for adult female elephant seals, however, BMR values predicted from Kleiber [81] have been shown to be within $10 \%$ of the metabolic rates of quiescent, submerged Weddell seals [82]. In addition, Lavigne et al. [63] found no difference between Kleiber's predicted BMRs of terrestrial mammals and the empirically-determined BMRs of similarly-sized, adult phocid seals when measured under similar conditions. For these reasons, we used Kleiber's predictions of BMR for terrestrial mammals to estimate the maintenance costs of the seals in this study.

Finally, after accounting for assimilation efficiency, HIF and BMR, any remaining cost was assumed to represent energy spent on locomotion.

With all costs and gains accounted for, we could then estimate the energy ingested from prey that was necessary to balance each seal's energy budget $\left(\mathrm{E}_{\text {INGESTED }}\right)$. We estimated the energy from prey our study animals would have needed to consume overall as well as on a per foraging dive basis. Foraging dives were determined using a custom-written dive typing script in MATLAB (IKNOS toolbox, Y. Tremblay, unpublished program), whereby the putative behavior of the seal is classified based on the two-dimensional shape of each dive as recorded by the TDR [30]. In addition to the sawtoothshaped dives traditionally classified as foraging, we included the V-shaped dives traditionally classified as transit, per recent evidence provided by Naito et al. [83] that demonstrates the high probability that northern elephant seals are foraging during these dives as well.

\section{Statistical analysis}

The influence of body size, time at sea and foraging migration (short or long trip) on field metabolic rate, locomotion costs and flipper stroking frequency, was investigated using multiple linear regression (MLR) models. Candidate models included the interaction term body size $\mathrm{x}$ migration to test whether the effect of body size on each of the response variables co-varied with migration, in which case we ran MLR models on each of the migrations separately. These MLRs included time at sea and its potential interaction with body size. Generalized least squares (GLS) models with variance structure fixed for mass were used to measure the association between body size and foraging migration and the proportion of ingested energy allocated towards mass gain and towards locomotion costs. All means are expressed as \pm S.E. of the mean, except where noted otherwise. Analyses were performed using the built-in 'lm' function, and the 'gls' function of the 'nlme' package in $\mathrm{R}$ 3.1.2 [84]. All model combinations were fitted with best model fits based on the lowest Akaike information criteria corrected for small sample size (AICc). Where $p$ values indicate significant differences $(p<0.05)$ between seals in the two groups, we report Cohen's $d$ effect sizes and effect-size correlation $r_{\gamma \lambda}[85,86]$, using the long foraging migration (when seals were pregnant) as the 'treatment' effect. In addition, we analyzed the sensitivity of FMR and locomotion cost model results to uncertainty in the estimates of input parameters using a Latin hypercube random sampling method that takes into account the range and distribution of each input parameter, as well as their interactions [87]. Sensitivity analyses were performed using the 'sensitivity', 'pse', 'ks' and 'Hmisc' packages in $\mathrm{R}$ and the Excel 'Apogee' add-in v.4.9 developed by the Statistical Design Institute (Additional file 1).

\section{Data accessibility}

All data used are present in the manuscript and its supporting information.

\section{Additional file}

Additional file 1: Table S1. Sensitivity results for calculations of field metabolic rate (FMR, in $\mathrm{kJ} \mathrm{kg}^{-1} \mathrm{day}^{-1}$ ) in adult, female northern elephant seals (Mirounga angustirostris) during the short and long foraging migrations. Table S2. Sensitivity results for calculations of locomotion costs (\%Locom, as a percentage of ingested prey energy used) in adult, female northern elephant seals (Mirounga angustirostris) during the short and long foraging migrations. (DOCX $18 \mathrm{~kb}$ )

\begin{abstract}
Abbreviations
ADL: Aerobic dive limit; CADL: Calculated aerobic dive limit; BMR: Basal metabolic rate $\left(\mathrm{kJ} \mathrm{kg}^{-1} \mathrm{~d}^{-1}\right)$; DAS: Time spent at sea $\left(\mathrm{d}^{-1}\right)$; DG: Drag treatment; refers to seals carrying added drag during the short foraging migration; DMR: Diving metabolic rate $\left(\mathrm{kJ} \mathrm{kg}^{-1} \mathrm{~d}^{-1}\right)$; FMR: Mass-specific field metabolic rate $\left(\mathrm{kJ} \mathrm{kg}^{-1} \mathrm{~d}^{-1}\right)$; FMR* : Absolute field metabolic rate $\left(\mathrm{kJ} \mathrm{d}^{-1}\right)$; HIF: Heat increment of feeding; LT: Long trip; refers to seals during the long foraging migration (pregnant); R: Stroke rate (strokes $\mathrm{d}^{-1}$ ); $\mathrm{Sn}$ : Total number of strokes; ST: Short trip; refers to seals during the short foraging migration (not pregnant); TDR: Time-depth recorder.
\end{abstract}

\section{Competing interests}

The authors declare that they have no competing interests.

\section{Authors' contributions}

$J \mathrm{LM}$ and DPC conceived of the question and design of the experiment. JLM, TA, AT and YN carried out the experiment. JLM analyzed the data. TA, AT, YN, DEC and TLW contributed to data interpretation. JLM wrote the first draft of this paper, and all authors read and approved the final manuscript. 


\section{Acknowledgements}

The authors would like to thank the Japan Society for the Promotion of Science for Grant-in-Aid 23255001 (A: 23255001 and B: 21380128) and the Tagging of Pacific Predators (TOPP) project. Partial funding was also received from the Office of Naval Research (N00014-03-0651, N00014-10-1-0356, N00014-13-1-0134), the Moore, Packard and Sloan Foundations, and the E \& P Sound and Marine Life Joint Industry Program (contract JIP22 07-23). JLM received additional support from a fellowship and several small grants administered by the Ecology and Evolutionary Biology Department at the University of California in Santa Cruz (UCSC). All procedures were approved by the Institutional Animal Care and Use Committee at UCSC, and the US NMFS (permits 87-1743-04 and 14636). The authors are grateful for the numerous field volunteers involved in data collection, particularly field crew leaders $\mathrm{M}$. Fowler, C. Goetsch, L. Hückstadt, S. Peterson and P. Robinson. Gratitude is also extended to the rangers and docents at the Año Nuevo State Reserve for their collaborative spirit, their continued support of research, and their genuine regard for the animals in their care.

\section{Author details}

'Department of Ecology \& Evolutionary Biology, University of California, Santa Cruz, USA. ${ }^{2}$ Department of Polar Science, Graduate University for Advanced Studies, Midoricho, Tachikawa, Japan. ${ }^{3}$ National Institute of Polar Research, Midoricho, Tachikawa, Japan. ${ }^{4}$ Department of Biology, Sonoma State University, Rohnert Park, USA. ${ }^{5}$ Department of Fisheries \& Wildlife, Marine Mammal Institute, Oregon State University, Newport, USA. ${ }^{6}$ University of California Center for Ocean Health/Long Marine Lab, 100 Shaffer Rd., Santa Cruz, CA 95060, USA.

Received: 2 April 2015 Accepted: 26 August 2015

Published online: 15 September 2015

\section{References}

1. Ripple WJ, Estes JA, Beschta RL, Wilmers CC, Ritchie EG, Hebblewhite M, et al. Status and ecological effects of the world's largest carnivores. Science. 2014;343:151-63.

2. Bowen WD. Role of marine mammals in aquatic ecosystems. Mar Ecol Prog Ser. 1997;158:267-74

3. Pauly D, Christensen V, Guénette S, Pitcher TJ, Sumaila UR, Walters CJ, et al. Towards sustainability in world fisheries. Nature. 2002;418:689-95.

4. Baum JK, Myers RA, Kehler DG, Worm B, Harley SJ, Doherty PA. Collapse and conservation of shark populations in the Northwest Atlantic. Science. 2003;299:389-92

5. Reynolds III JE. Marine mammal research: conservation beyond crisis. Baltimore, MD: JHU Press; 2005.

6. Block BA, Jonsen ID, Jorgensen SJ, Winship AJ, Shaffer SA, Bograd SJ, et al. Tracking apex marine predator movements in a dynamic ocean. Nature. 2011;475:86-90.

7. Goetz KT, Rugh DJ, Read AJ, Hobbs RC. Habitat use in a marine ecosystem: Beluga whales Delphinapterus leucas in Cook Inlet, Alaska. Mar Ecol Prog Ser. 2007:330:247-56.

8. Rutz C, Hays GC. New frontiers in biologging science. Biol Lett. 2009;3:289-92

9. McNab BK. The influence of food habits on the energetics of eutherian mammals. Ecol Monog. 1986;56:1-19.

10. Speakman JR, Król E. Maximal heat dissipation capacity and hyperthermia risk: neglected key factors in the ecology of endotherms. J Anim Ecol. 2010;79:726-46

11. Krebs JR, Davies NB. Behavioural ecology: an evolutionary approach. Oxford: Blackwell; 2009.

12. Boyd IL. Energetics: consequences for fitness. In: Hoelzel AR, editor. Marine mammal biology: an evolutionary approach. Oxford: Blackwell Science; 2002. p. 247-77.

13. Pianka ER. Convexity, desert lizards, and spatial heterogeneity. Ecol. 1966;47:1055-9.

14. Fish FE. Influence of hydrodynamic design and propulsive mode on mammalian swimming energetics. Austr J Zool. 1994;42:79-101.

15. Williams TM. Swimming by sea otters: adaptations for low energetic cost locomotion. J Comp Physiol A - Sens Neur Behav Physiol. 1989;164:815-24.

16. Crocker DE, LeBoeuf BJ, Costa DP. Drift diving in female northern elephant seals: implications for food processing. Can J Zool. 1997;75:27-39.
17. Nowacek DP, Johnson MP, Tyack PL, Shorter KA, McLellan WA, Pabst DA. Buoyant balaenids: the ups and downs of buoyancy in right whales. Proc Royal Soc B. 2001;268:1811-6.

18. Williams TM, Davis RW, Fuiman LA, Francis J, Le Boeuf BL, Horning M, et al. Sink or swim: strategies for cost-efficient diving by marine mammals. Science. 2000;288:133-6.

19. Au D, Weihs D. At high speeds dolphins save energy by leaping. Nature. 1980;284:548-50

20. Williams TM, Friedl WA, Fong ML, Yamada RM, Sedivy P, Haun JE. Travel at low energetic cost by swimming and wave-riding bottlenose dolphins. Nature. 1992;355:821-3.

21. Le Boeuf BJ, Crocker DE, Costa DP, Blackwell SB, Webb PM, Houser DS. Foraging ecology of northern elephant seals. Ecol Monogr. 2000;70:353-82.

22. Crocker DE, Williams JD, Costa DP, Le Boeuf BJ. Maternal traits and reproductive effort in northern elephant seals. Ecol. 2001;82:3541-55.

23. Maresh JL, Simmons SE, Crocker DE, McDonald Bl, Williams TM, Costa DP. Free-swimming northern elephant seals have low field metabolic rates that are sensitive to an increased cost of transport. J Exp Biol. 2014;217:1485-95.

24. Nagy KA. Field metabolic rate and food requirement scaling in mammals and birds. Ecol Monogr. 1987;57:111-28.

25. Nagy KA. Field metabolic rate and body size. J Exp Biol. 2005;208(Pt 9):1621-5.

26. Nagy KA, Girard IA, Brown TK. Energetics of free-ranging mammals, reptiles, and birds. Ann Rev Nutr. 1999;19:247-77.

27. Reilly JJ, Fedak MA. Rates of water turnover and energy expenditure of freeliving male common seals (Phoca vitulina). J Zool. 1991;223:461-8.

28. Nagy KA. Field bioenergetics of mammals: What determines field metabolic rates? Austr J Zool. 1994;42:43-53.

29. Costa DP, Trillmich F. Mass changes and metabolism during the perinatal fast: a comparison between Antarctic (Arctocephalus gazella) and Galapagos fur seals (Arctocephalus galapagoensis). Physiol Zool. 1988;61:160-9.

30. Lavigne DM, Innes S, Worthy GAJ, Kovacs KM, Schmitz OJ, Hickie JP. Metabolic rates of seals and whales. Can J Zool. 1986;64:279-84.

31. Meir JU, Champagne CD, Costa DP, Williams CL, Ponganis PJ. Extreme hypoxemic tolerance and blood oxygen depletion in diving elephant seals. Am J Physiol-Regul Integr Comp Physiol. 2009:297:R927-R39.

32. Webb PM, Andrews RD, Costa DP, Le Boeuf BJ. Heart rate and oxygen consumption of northern elephant seals during diving in the laboratory. Physiol Zool. 1998;71:116-25.

33. Houser DS, Crocker DE, Tift MS, Champagne CD. Glucose oxidation and nonoxidative glucose disposal during prolonged fasts of the northern elephant seal pup (Mirounga angustirostris). Am J Physiol-Regul Integr Comp Physiol. 2012;303:R562-R70.

34. Tift MS, Ranalli EC, Houser DS, Ortiz RM, Crocker DE. Development enhances hypometabolism in northern elephant seal pups (Mirounga angustirostris). Func Ecol. 2013;27:1155-65.

35. Brody S. Bioenergetics and growth: with special reference to the efficiency complex in domestic animals. Oxford: Reinhold Publishing Corporation; 1945.

36. Gittleman $J$, Thompson SD. Energy allocation in mammalian reproduction. Am Zool. 1988;28:863-75.

37. Renouf D, Gales R. Seasonal variation in the metabolic rate of harp seals: unexpected energetic economy in the cold ocean. Can J Zool. 1994;72:1625-32.

38. Kooyman GL, Wahrenbrock EA, Castellini MA, Davis RW, Sinnett EE. Aerobic and anaerobic metabolism during voluntary diving in Weddell seals: evidence of preferred pathways from blood chemistry and behavior. J Comp Physiol. 1980;138:335-46.

39. Le Boeuf BJ, Costa DP, Huntley AC, Feldkamp SD. Continuous, deep diving in female northern elephant seals, Mirounga angustirostris. Can J Zool. 1988;66:446-58.

40. Hindell MA, Slip DJ, Burton HR, Bryden MM. Physiological implications of continuous, prolonged, and deep dives of the southern elephant seal (Mirounga leonina). Can J Zool. 1992;70:370-9.

41. Hassrick JL, Crocker DE, Teutschel NM, McDonald Bl, Robinson PW, Simmons $\mathrm{SE}$, et al. Condition and mass impact oxygen stores and dive duration in adult female northern elephant seals. J Exp Biol. 2010;213:585-92.

42. Kooyman GL. Diverse divers: physiology and behavior. Berlin: Springer; 1989.

43. Scholander PF. Experimental investigations on the respiratory function in diving mammals and birds. Hvøalradets Skrifter. Norske Videnskaps-Akad.: Oslo; 1940. 
44. Butler PJ, Jones DR. Physiology of diving of birds and mammals. Physiol Rev. 1997;77:837-99.

45. Tyack PL, Johnson M, Soto NA, Sturlese A, Madsen PT. Extreme diving of beaked whales. J Exp Biol. 2006:209:4238-53.

46. Watwood SL, Miller PJO, Johnson M, Madsen PT, Tyack PL. Deep-diving foraging behaviour of sperm whales (Physeter macrocephalus). J Anim Ecol. 2006;75:814-25.

47. Davis RW, Fuiman LA, Williams TM, Collier SO, Hagey WP, Kanatous SB, et al. Hunting behavior of a marine mammal beneath the Antarctic fast ice. Science. 1999:283:993-6.

48. Sato K, Mitani Y, Cameron MF, Siniff DB, Naito Y. Factors affecting stroking patterns and body angle in diving Weddell seals under natural conditions. J Exp Biol. 2003;206:1461-70.

49. Adachi T, Maresh JL, Robinson PW, Peterson SH, Costa DP, Naito Y, et al. The foraging benefits of being fat in a highly migratory marine mammal. Proc Royal Soc B: Biol Sci. 2014;281:20142120.

50. Aoki K, Watanabe YY, Crocker DE, Robinson PW, Biuw M, Costa DP, et al. Northern elephant seals adjust gliding and stroking patterns with changes in buoyancy: validation of at-sea metrics of body density. J Exp Biol. 2011;214(Pt 17):2973-87.

51. Miller PJ, Biuw M, Watanabe YY, Thompson D, Fedak MA. Sink fast and swim harder! Round-trip cost-of-transport for buoyant divers. J Exp Biol. 2012;215(Pt 20):3622-30.

52. Watanabe Y, Baranov EA, Sato K, Naito Y, Miyazaki N. Body density affects stroke patterns in Baikal seals. J Exp Biol. 2006;209(Pt 17):3269-80.

53. Vazquez-Medina JP, Zenteno-Savin T, Tift MS, Forman HJ, Crocker DE, Ortiz RM. Apnea stimulates the adaptive response to oxidative stress in elephant seal pups. J Exp Biol. 2011;214(Pt 24):4193-200.

54. Sakamoto W, Naito Y, Huntley AC, Leboeuf BJ. Daily gross energy requirements of a female northern elephant seal Mirounga angustirostris at sea. Nippon Suisan Gakkaishi. 1989:55:2057-63.

55. Jones TT, Van Houtan KS, Bostrom BL, Ostafichuk P, Mikkelsen J, Tezcan E, et al. Calculating the ecological impacts of animal-borne instruments on aquatic organisms. Methods Ecol Evol. 2013;4:1178-86.

56. Hazekamp AA, Mayer R, Osinga N. Flow simulation along a seal: the impact of an external device. Euro J Wildlife Res. 2010:56:131-40.

57. Culik BM, Bannasch R, Wilson RP. External devices on penguins: how important is shape? Mar Biol. 1994;118:353-7.

58. New LF, Harwood J, Thomas L, Donovan C, Clark JS, Hastie G, et al. Modelling the biological significance of behavioural change in coastal bottlenose dolphins in response to disturbance. Func Ecol. 2013;27:314-22.

59. Villegas-Amtmann S, Schwarz LK, Sumich JL, Costa DP. Population consequences of lost foraging opportunity in eastern female gray whales. Ecosphere. 2015 (in press).

60. Brodie PF. Cetacean energetics, an overview of intraspecific size variation. Ecol. 1975:56:152-61.

61. Blix AS, Folkow LP. Daily energy expenditure in free living minke whales. Acta Physiol Scand. 1995;153:61-6.

62. Mitani Y, Andrews RD, Sato K, Kato A, Naito Y, Costa DP. Three-dimensional resting behaviour of northern elephant seals: drifting like a falling leaf. Biol Lett. 2010;6:163-6.

63. Lavigne DM, Innes S, Stewart REA, Worthy GAJ. An annual energy budget for north-west Atlantic harp seals. In: Beddington JR, Beverton RJH, Lavigne DM, editors. Marine mammals and fisheries. London: George Allen \& Unwin; 1985. p. 319-36.

64. Costa DP. A bioenergetics approach to developing a population consequences of acoustic disturbance model. In: Popper AN, Hawkins A editors. The effects of noise on aquatic life. Springer Science + Business Media, LLC; 2012. p. 423-7.

65. Watts $P$, Hansen S, Lavigne DM. Models of heat loss by marine mammals: thermoregulation below the zone of irrelevance. J Theor Biol. 1993;163:505-25.

66. Noren DP. Thermoregulation of weaned northern elephant seal (Mirounga angustirostris) pups in air and water. Physiol Biochem Zool. 2002;75:513-23.

67. Simmons SE, Crocker DE, Hassrick JL, Kuhn CE, Robinson PW, Tremblay Y, et al. Climate-scale hydrographic features related to foraging success in a capital breeder, the northern elephant seal Mirounga angustirostris. Endan Spec Res. 2010;10:233-43.

68. Robinson PW, Simmons SE, Crocker DE, Costa DP. Measurements of foraging success in a highly pelagic marine predator, the northern elephant seal. J Anim Ecol. 2010;79:1146-56.
69. Hedd A, Gales R, Renouf D. Inter-annual consistency in the fluctuating energy requirements of captive harp seals Phoca groenlandica. Polar Biol. 1997;18:311-8.

70. Sparling CE, Speakman JR, Fedak MA. Seasonal variation in the metabolic rate and body composition of female grey seals: fat conservation prior to high-cost reproduction in a capital breeder? J Comp Physiol B. 2006;176:505-12

71. Sparling CE, Fedak MA. Metabolic rates of captive grey seals during voluntary diving. J Exp Biol. 2004;207:1615-24.

72. Ochoa-Acuna HG, McNab BK, Miller EH. Seasonal energetics of northern phocid seals. Comp Biochem Physiol A. 2009;152:341-50.

73. Keiver KM, Ronald K, Beamish FWH. Metabolizable energy requirements for maintenance and faecal and urinary losses of juvenile harp seals (Phoca groenlandica). Can J Zool. 1984;62:769-76.

74. Parsons JL. Metabolic studies on the ringed seal Phoca hispida. Thesis (M. Sc.): University of Guelph; 1977.

75. Costa DP, Williams TM. Marine mammal energetics. In: Reynolds III JE, Rommel SA, editors. Biology of Marine Mammals. Washington, DC: Smithsonian Institution Press; 1999. p. 176-217.

76. Barbour AS. Heat increment of feeding in juvenile northern elephant seals. Santa Cruz: Thesis (M.Sc.); 1993.

77. Costa DP, Kooyman GL. Contribution of specific dynamic action to heat balance and thermoregulation in the sea otter Enhydra lutris. Physiol Zool. 1984;57:199-203.

78. Gallivan G, Ronald K. Apparent specific dynamic action in the harp seal (Phoca groenlandica). Comp Biochem Physiol A: Physiol. 1981;69:579-81.

79. Lavigne DM. Similarity in energy budgets of animal populations. J Anim Ecol. 1982;51:195-206.

80. Ashwell-Erickson SM, Elsner R. The energy cost of free existence for Bering Sea harbor and spotted seals. University of Alaska, Fairbanks: Thesis (M.Sc.); 1981.

81. Kleiber M. The fire of life: an introduction to animal energetics. 2nd ed. New York: Kreiger; 1975.

82. Williams TM, Fuiman LA, Horning M, Davis RW. The cost of foraging by a marine predator, the Weddell seal Leptonychotes weddellii: pricing by the stroke. J Exp Biol. 2004;207:973-82.

83. Naito Y, Costa DP, Adachi T, Robinson PW, Fowler MA, Takahashi A. Unravelling the mysteries of a mesopelagic diet: a large apex predator specializes on small prey. Func Ecol. 2013;27:710-7.

84. R Core Team. R: a language and environment for statistical computing Vienna, Austria: R Foundation for Statistical Computing. http://www.rproject.org; 2014.

85. Cohen J. A power primer. Psychol Bull. 1992;112:155-9.

86. Rosnow RL, Rosenthal R, Rubin DB. Contrasts and correlations in effect-size estimation. Psychol Sci. 2000;11:446-53.

87. Hamby D. A review of techniques for parameter sensitivity analysis of environmental models. Envir Monit Assess. 1994;32:135-54.

\section{Submit your next manuscript to BioMed Central and take full advantage of:}

- Convenient online submission

- Thorough peer review

- No space constraints or color figure charges

- Immediate publication on acceptance

- Inclusion in PubMed, CAS, Scopus and Google Scholar

- Research which is freely available for redistribution 